\title{
Refleksi Etika Kebahagiaan dalam Novel Khotbah di Atas Bukit Karya Kuntowijoyo
}

\section{Lina Santiana}

Fakultas Ushuluddin dan Pemikiran Islam

Universitas Islam Negeri Raden Fatah Palembang, Indonesia

Email: santianalina@gmail.com

\begin{abstract}
Abstrak
Novel Khotbah Di Atas Bukit Karya Kuntowijoyo mengandung nilai-nilai etika kebahagiaan yang sama dengan Epikuros. Dimana Epikuros menghendaki untuk mencapai kebahagiaan seseorang harus mencari nikmat yang sebanyakbanyaknya dengan menghindari pertanyaan-pertanyaan, dan pikiran-pikiran yang membuat kesakitan badan dan jiwa. dengan itu Epikuros menghendaki keutamaan-keutamaan seperti kesederhanaan, tahu diri, penguasaan diri dan kebijaksanaan. Bergitu pula dalam Novel Khotbah Di Atas Bukit Karya Kuntowijoyo, dimana kuntowijoyo dalam novel khotbah di atas bukit menghendaki agar untuk bahagia seseorang harus mencari nikmat dan menghindari segala hal yang membuat kesakitan badan, sehingga jiwa menjadi resah. Dengan memperhatikan keutamaan seperti, kesederhanaan, penguasaan diri, dan kebijaksanaan.
\end{abstract}

\begin{abstract}
Kuntowijoyo's novel "Khotbah Di Atas Bukit" containing ethical values of happiness in common with the Epicurean. Where Epicurean desires to achieve happiness, one must find favor as much as possible to avoid the questions and thoughts that make body and soul in the pain. With it, the Epicurean requires virtues such as modesty, knowing oneself, self-control and wisdom. Similarly, in the Kuntowijoyo's Novel "Khotbah Di Atas Bukit”, Kuntowijoyo requires that to be happy one must seek favor and avoid pain of all the things that make the body and the soul becomes restless. Having regard to such virtues, modesty, self-control and wisdom.
\end{abstract}

Keywords: Ethics, Epicurean, Happiness

Intizar, Vol. 22, No. 1, 2016 
Kebahagiaan adalah keadaan subjektif yang dengan itu seseorang merasa dalam dirinya ada kepuasan atas keinginannya, dan sadar dirinya memiliki sesuatu yang baik. ${ }^{1}$ Karena kebahagiaan itu merupakan keadaan yang subjektif maka, setiap orang bahkan setiap agama pun memiliki pandangan yang berbeda-beda dalam mengartikan kebahagiaan. Bahkan untuk mencapai kebahagiaan itu pun memiliki jalan yang berbeda-beda. Dalam Islam, pusat segala kebahagiaan adalah saat seseorang bertemu dengan sang kholiq. ${ }^{2}$ Untuk sampai kepada kebahagiaan itu, maka seseorang harus bertakwa. Menghindari segala yang dilarang-NYA dan mengerjakan apa yang diperintahkan oleh Allah, untuk mencapai kebahagiaan dunia dan akhirat.

Sedangkan dalam agama Hindu kebahagiaan sejati adalah ketika manusia telah mampu mencapai keadaan Sat-Cit-Ananda. ${ }^{3}$ Keadaan dimana manusia telah mampu merasakan kehadiran Tuhannya, dengan sikap yang paling tepat yaitu bahwa manusia harus berbakti kepada Tuhan, menghormati dan dengan cinta menyerahkan diri secara total kepada Tuhan agar di anugrahi persatuan kebahagiaan bersamanya. ${ }^{4}$ sedangkan Dalam pandangan Taoisme ${ }^{5}$ kebahagiaan itu adalah keadaan dimana manusia telah mencapai Tao. ${ }^{6}$ Karena Tao melebihi surga. Dan untuk mencapai kebahagiaan dan kedamaian itu maka manusia harus mentaati hukum. $^{7}$

Kebahagiaan dalam pandangan filsafat memiliki arti tersendiri yaitu, kebahagiaan adalah tujuan dan motif terdasar dari segala yang dikerjakan. Menurut Aristoteles kebahagiaan diartikan sebagai kesempurnaan kegiatan dari manusia sebagai manusia. ${ }^{8}$ Oleh karena itu, seseorang apabila menjalankan fungsinya sebagai manusia dengan baik, ia akan mencapai tujuan terakhirnya atau kebahagiaan. Adapun kaum Epikureanisme beranggapan bahwa kebahagiaan itu adalah keadaan dimana manusia dapat menikmati kenikmatan dan terhindar dari segala hal yang menyakitkan. Sehingga tercapainya ketenangan jiwa. ${ }^{9}$

Dari sekian banyak pandangan tentang kebahagiaan, tetap memiliki tujuan yang sama yaitu untuk mencapai kebaikan dan kebahagiaan, hanya cara pandangnya yang membedakan. Namun pada dasarnya, kesemuanya ingin mengarahkan hidup manusia pada kebaikan dan meninggalkan keburukan, untuk dapat hidup bermoral dan mencapai kebahagiaan. Maka dari itu manusia membutuhkan etika dalam hidupnya. Sejatinya, etika adalah ilmu yang mengajarkan manusia bagaimana seharusnya hidup. Sebagaimana pandangan Epikuros, etika adalah pusat seluruh filsafat ${ }^{10}$. Sebab manusia membutuhkan etika untuk dapat hidup sebagai manusia yang sehat jiwa dan raganya. ${ }^{11}$ Sedangkan 


\section{Lina Santiana}

menurut Plato etika adalah ilmu yang individu atau kolektif masyarakat. Oleh sebab itu, wacana etika mempunyai unsur-unsur pokok. Unsur-unsur pokok itu adalah kebebasan, tanggung jawab, hati nurani, dan prinsif-prinsif moral dasar. ${ }^{12}$ Hal-hal yang dikaji dalam etika adalah apa yang menjadi tujuan hidup manusia. Tujuan hidup manusia yang menjadi maenstro bagi manusia dan itulah yang terbaik bagi manusia. Persoalannya adalah apakah yang menjadi tujuan hidup manusia? Lalu apakah manusia akan berbuat sesuai dengan tujuan hidupnya atau tidak? ${ }^{13}$

Oleh karena itu, etika sangat penting untuk dipelajari, perkembangan budaya yang pesat saat ini baik di bidang ilmu pengetahuan, ekonomi, politik, kesenian, dan lain-lain membawa perubahan baru bagi peradaban manusia. Tidak saja dengan perangkat-perangkat IPTEK yang berkembang, tetapi pengaruh ideologi baru pun mulai ibarat jamur yang tumbuh di musim hujan. Seiring dengan kemajuan Budaya, tawaran-tawaran iptek yang menggiurkan menjadikan budaya manusia tumbuh semakin kompleks, bahkan plural. Pada sebagian manusia kondisi ini membuat manusia kebingungan. ${ }^{14}$ Pandangan hidup telah diubah menjadi material oriented, yaitu materi sebagai ukuran, sehingga manusia sedemikian diperhamba oleh teknologi yang telah menjauhkan manusia dari komunal yang hakiki. Kuntowijoyo menamakan hal semacam ini sebagai akibat urban culture yang bertentangan dengan nilai-nilai masyarakat tradisional agraris, yaitu masyarakat kota yang semakin nisbi dengan nilai kemasyarakatannya dalam arti yang hakiki. ${ }^{15}$

Itu semua terjadi karena manusia telah kehilangan identitas dirinya sebagai manusia dan sudah kehilangan orientasi hidup. Padahal salah satu kebutuhan manusia yang fundamental adalah "orientasi”. Sebab manusia dalam melakukan apa pun harus mencari orientasi terlebih dahulu. Maka manusia harus mengetahui dirinya berada dan kearah mana ia bergerak untuk mencapai tujuan. ${ }^{16}$ Sulit untuk di bantah bahwa manusia terus menerus mengejar hal yang baik. ${ }^{17}$ Dalam keadaan semacam itu manusia akan tersentuh dibenaknya, dimana ia akan menempatkan diri. Kadang ia di desak oleh dorongan nafsaniahnya, makan dan minum, pangkat dan kedudukan, dan mengejar keuntungan harta menjadi tujuan utama. ${ }^{18}$

Namun, ketika manusia berhenti untuk berpikir di tengah aktivitas yang menakutkan ini, pertanyaan berikut mungkin muncul di benak seseorang: jika seseorang itu dapat perkerjaan yang baru, jika seseorang itu memperoleh mobil yang lebih bagus, Apa gunanya semua itu? Apakah manusia adalah orang yang benar-benar menginginkan semua itu? Pertanyaan pertanyaan seperti ini, kapan

Intizar, Vol. 22, No. 1, 2016 
pun muncul, adalah menakutkan, karena itu semua adalah pertanyaan mendasar yang diatasnya seluruh aktivitas manusia dibangun: pengetahuannya akan apa yang ia inginkan. ${ }^{19}$

Oleh karena, kehidupan manusia saat ini serba instan sedangkan kemakmuran ternyata tidak berhasil menghantarkan manusia kepada kebahagiaan yang hakiki. Justru di tengah kehidupan ini terlihat adanya kegelisahan pada sejumlah kelompok manusia. Jiwa manusia Nampak gersang padahal manusia bergelimang dengan kemewahan dunia. ${ }^{20}$ Maka disinilah peran etika untuk mengarahkan manusia dalam mencapai tujuannya kepada kebaikan.

Melihat upaya untuk membina etika dengan berbagai macam cara telah dilakukan oleh banyak orang, mulai dari ketika pada masa para Filosof bahkan para Sastrawan lewat karya-karya yang telah dihasilkan. Etika terus di bahas dan dipelajari. Etika bukan hanya membahas tentang tingkah laku, dan perilaku manusia. Namun dewasa ini etika juga membahas tentang kebahagiaan, nilai, tanggung jawab, hak dan kewajiban. Dewasa ini juga pembahasan etika tidak lagi selalu menggunakan karya yang bersifat ilmiah akan tetapi, pembahasan etika dapat pula didekati melalui karya satra, prosa, bahkan melalui puisi-puisi, lukisan dan sebagainya. Seperti halnya Kuntowijoyo, Salah satu diantara banyak sastrawan yang telah banyak ikut menyumbangkan hasil pemikirannya di dunia sastra seperti Iwan Simatupang, Danarto, Budi Darma, Arifin. C. Noer dan masih banyak lainnya. Kuntowijoyo adalah salah satu dari sekian banyak sastrawan yang telah mencoba memadukan nilai-nilai etika yang bergitu luhur lewat salah satu karyanya yang berjudul Khotbah Di Atas Bukit, meskipun pada masa terbitnya novel ini pembaca banyak yang mencemooh dan menyesalkan publikasi novel tersebut di surat kabar manusia, sehingga tidak banyak kritikus sastra yang menaruh perhatian kepada novel ini. Meskipun demikian, Kuntowijoyo telah berhasil mencoba memadukan nilai-nilai etika dalam banyak sastra yang dihasilkannya termasuk novel khotbah di atas bukit ini.

Atas dasar inilah maka, penulis mencoba mengangkat kiprah seni sastra Kuntowijoyo sebagai seorang pujangga sastra Indonesia, lewat karya sastranya "Novel Khotbah Di Atas Bukit", yang tanpa di sadari telah mengajak pembaca untuk mengenal etika kebahagiaan. Karena Kuntowijoyo ini adalah pujangga yang berprestasi melalui karya-karyanya seperti dilarang mencintai bunga-bunga dan termasuk novel khotbah di atas bukit ini dan masih banyak lainnya, yang sarat dengan makna hidup. Sehingga penulis tertarik untuk mendalami sejauh mana

Intizar, Vol. 22, No. 1, 2016 
etika kebahagiaan yang ada dalam Novel Khotbah Di Atas Bukit Karya Kuntowijoyo.

\section{Makna Kebahagiaan Dalam Novel Khotbah Di Atas Bukit Karya Kuntowijoyo}

Kebahagiaan adalah keinginan yang terpuaskan karena disadari memiliki sesuatu yang baik. ${ }^{21}$ Kebahagiaan menurut Epikuros apakah yang lebih menandai kodrat manusiawi kita daripada menghindari ketidaksenangan, nyeri penderitaan, serta kesedihan dan mencari yang enak, kesenangan, kenikmatan? Dari sini terlehat jelas bahwa kesenangan adalah prinsip serta tujuan dari hidup bahagia. ${ }^{22}$ Kesenangan adalah hal pertama yang cocok dengan kodrat kita. Dari kesenanganlah kita bertolak untuk menolak atau menghindari benda-benda dan pada kesenanganlah kita sampai, bila kita memilih perasaan sebagai norma untuk yang baik.

Dalam novel Khotbah Di Atas Bukit, Kuntowijoyo menggambarkan bahwa kebahagiaan adalah sesuatu yang senantiasa di cari oleh setiap orang. Manusia senantiasa mendambakannya dan senantiasa berusaha untuk mendapatkannya. Sebagaimana yang dituliskan oleh Kuntowijoyo, "kebahagiaan juga terdapat di puncak gunung." Ini menunjukkan bahwa seseorang yang ingin bahagia senantiasa mencari kebahagiaannya dimanapun dia berada baik di kota, di desa, di kesunyian bahkan dipuncak gunung pun, seseorang ingin bahagia. Dan disetiap hidupnya seseorang senantiasa mendambakan kebahagiaan dan senantiasa mencari kebahagiaan, sebagaimana Kuntowijoyo menuliskan;

"Apa yang kau cari bung?" orang itu bertanya lagi.

"Tunggulah kata orang itu" ayo kita masuk. Akan aku ceritakan kepadamu apa yang sedang kau cari sebenarnya. Setiap orang yang datang ke bukit ini mesti mencari sesuatu. ${ }^{23}$

"Sekarang ia ingin memulai sesuatu yang baru sama sekali, yang seperti ketika dia dilahirkan tak membawa apa-apa, juga pikiranpikiran. Ia ingin sesuatu yang murni. Barman berharap hidup murni itu akan dapat dilakukannya di bukit. ..... Ia akan memulai hidup lagi seperti semua orang pada mulanya hidup, telanjang dan mencari-cari. Ia merasa terhormat dengan keputusannya itu.",24

Dari cuplikan novel Khotbah di Atas Bukit tersebut bahwa, Seseorang akan melakukan apa saja yang dirasakan baik olehnya untuk mendapatkan kebahagiaan, ketenangan dan kenikmatan hidup. Termasuk pergi ke bukit 
menjalani hidup baru dan meninggalkan segala masa lalu. Akan tetapi sejatinya kebahagiaan adalah sesuatu yang menjadi tujuan oleh setiap orang, maka apabila tujuan hidup ini belum tercapai seseorang akan merasakan resah dan merasakan ada sesuatu yang hilang dari dirinya. Sebagaimana Kuntowijoyo mengambarkan dengan lembut bahwa setelah Barman bertemu dengan Humam ada sesuatu yang hilang dalam dirinya, ditengah kemewahan, kecukupan hidup dan perempuan cantik yang hidup bersamanya di bukit itu. Sedangkan dalam novel tersebut Humam yang hidup dengan sederhana, tanpa beban dan penuh dengan kebijaksaan dapat menikmati setiap waktu dengan kecerian. Inilah yang membuat Barman merasakan ada sesuatu yang hilang dari hidupnya. Sebagaiman dituliskan Kuntowijoyo;

"Barman memandang lauk pauk di meja itu. Macam yang belum pernah ditemuinya.... Nampak sahabat yang menjamunya itu periang. Tidak ada tanda-tanda ketuanya padanya, kecuali ototototnya.... Waktu masih akan lama lagi bersamanya.,25

"Barman teringan, gambar-gambar filsuf dan penyair cina yang memancing. Apakah Humam itu penyair atau filsuf? Wajahnya sungguh keriput dan tua, matanya memancarkan sinar kegembiraan yang telah mencapai sesuatu dalam hidupnya. Sedangkan ia sendiri kini merasa kehilangan sesuatu, yang dicarinya dan tidak ketemu. Sesuatu yang jauh semacam kegelisahan selalu mengejar dirinya."26

Terlebih ketika Humam mengajarkan kepada Barman bahwa; "Tinggalkan segala milikmu. Apa saja yang menjadi milikmu sebenarnya memilikimu. Dan engkau tidak lagi merdeka. Engkau mengira itu kekuasaan, tidak. Itu membuatmu takhluk. Membelenggu!."27 Kuntowijoyo juga menuliskan, "juga cinta adalah belenggu kita!."28 Dari sini terlihat jelas bahwa, menurut Kuntowijoyo kebahagiaan adalah dimana seseorang bebas dari segala hal yang membuat dirinya terbelenggu, karena harta, wanita, dan bahkan karena cinta. Sebagaimana dituliskan oleh Kuntowijoyo bahwa, "kebahagiaan mutlah, tak memelukan apaapa di luat diri kita.",29

Selain hal di atas, Kuntowijoyo juga menggambarkan bahwa hidup bahagia adalah ketika seseorang dapat menjalankan kewajibannya dengan kesadaran diri, dengan tulus dan sepenuh hati. Tanpa paksaan dan itu dilakukan atas kehendaknya sendiri. Sebagaimana dituliskan Kuntowijoyo melalui tokoh Popi yang memutuskan untuk menghabiskan hidupnya bersama laki-laki tua itu,

Intizar, Vol. 22, No. 1, 2016 


\section{Lina Santiana}

dan menjalankan segala kewajibannya dengan sepenuh hati, "Ia telah menjadi bagian dari yang harus dikerjakannya, kewajibannya. Ia suka kepada kewajiban itu. Dan ia telah memutuskan untuk memuliakannya bagaimanapun.... Sebab ia sudah bahagia karenanya." ${ }^{30}$ Dari sini terlihat bahwa Kuntowijoyo ingin menyampaikan bahwa kebahagiaan itu dapat dimiliki oleh seseorang ketika seseorang itu dapat menikmati dan menerima segala yang telah ia putuskannya untuk dilakukannya. Dengan menyukai setiap aktivitas kehidupan dan menjalaninya dengan sepenuh hati.

Kemudian Kuntowijoyo juga menggambarkan bahwa kebahagiaan itu adalah dimana seseorang telah merasakan dalam dirinya kebebasan dan kebijaksanaan hidup. Dia mampu menikmati setiap waktu, dia mampu menikmati setiap perjalanan dari hidup ini dengan tenang dan penuh dengan kebijaksanaan. Jika seseorang telah sampai pada hal tersebut. Maka ia akan mencapai kebahagiaan. Sebagaimana yang dituliskan oleh Kuntowijoyo lewat tokoh Humam;

"Waktu, sesuatu yang harus kita nikmati seperti juga benda lainnya. Engkau mesti belajar dari hidup ini. ${ }^{31}$ Lupakan semuanya bahkan dirimu. Yang ada ialah pohon-pohon, rumpus-rumput. Engkau makhluk yang paling berbahagia. Waktu ialah untuk dinikmati. Ruang ialah tempat kita bergerak. Gerak ialah hidup kita."32

Kuntowijoyo lewat novel Khotbah Di Atas Bukit ini juga ingin menyampaikan bahwa, manusia harus hidup dengan sederhana, sekedarnya dan tidak di buat-buat. serta berbahagia sebesar-besarnya. Sebagaimana dituliskan oleh Kuntowijoyo, lewat tokoh Humam "hidup sekadarnya, bahagia sebesarnya."33

Melihat hal di atas, Kuntowijoyo lewat novel Khotbah Di Atas Bukit menghendaki bahwa manusia dalam hidupnya hendaklah mencari kebahagiaan dengan sedapat-dapatnya. Bukan hanya dengan kekayaan, jabatan, dan wanita, serta kecukupan hidup, karena kadang semua itu adalah hal yang justru tidak membahagiaan. Maka dari itu Kuntowijoyo menggambarkan lewat tokoh Humam, menghedaki agar manusia hidup dengan sedemikian rupa, hidup dengan sederhana yang membuat kebahagiaan dan meninggalkan yang hal-hal bersifat sia-sia. Dan Kuntowijoyo juga ingin menyampaikan bahwa manusia hendaklah bahagian sebesar-besarnya dan mampu memilih mana yang dapat membahagiakan mana yang membuat ketidak senangan.

Kuntowijoyo menuliskan lewat tokoh Popi bahwa, untuk mencapai kebahagian kita harus membuang ingatan, pertanyaan-pertanyaan yang dapat 
membuat jiwa resah. “... Segalanya yang menyebabkan engkau menderita, sakit dan mendekatkan kematian, harus dipandang sebagai kejahatan. Tak lebih. Atau selebihnya adalah lamunan yang sia-sia...."

Dari penjelasan di atas maka dapat disimpulkan, dalam novel Khotbah Di Atas Bukit ini makna kebahagiaan bagi Kuntowijoyo adalah dimana seseorang dapat merasakan ketenangan jiwa, mampu mengedalikan diri, bebas dan dapat menikmati setiap waktu yang ada. Hidup dengan tulus murni dan seadanya. Hal ini sama dengan pandangan Epikuros yang menghendaki agar seseorang untuk bahagian harus meninggalkan segala yang menyakitkan dan senantiasa mencari ketenangan jiwa dengan pola hidup sederhana, kebijaksanaan dan penguasaan diri serta menghilangkan rasa takut. ${ }^{35}$ Bahkan Epikuros memuji keutamaan-keutamaan seperti tau diri, penguasaan diri, dan kegembiraan pada semua situasi. ${ }^{36}$

\section{Faktor-Faktor Pendukung Tercapainya Kebahagiaan}

Adapun faktor-faktor pendukung tercapainya kebahagiaan dalam novel Khotbah Di Atas Bukit karya Kuntowijoyo adalah sebagai berikut:

1. Kemampuan menikmati setiap waktu yang ada. Menurut Kuntowijoyo seseorang akan bahagia apabila dapat menikmati setiap waktu yang ada dengan sepenuh hati. Sebagaimana yang dituliskan oleh Kuntowijoyo.

"Lupakan semuanya. Bahkan dirimu. Yang ada ialah pohon-pohon, rumput-rumput.... Waktu ialah untuk dinikmati. Ruang ialah tempat kita bergerak. Dan gerak ialah hidup kita." ${ }^{37}$ Dan "Setiap yang bergerak dari hidup ini, setiap yang terdiam dari hidup ini, ialah untuk dinikmati... karena hidup itu mengasyikkan, maka bagian yang paling sepi pun menggembirakan. ${ }^{, 38}$

Kuntowijoyo juga menuliskan lewat tokoh Popi bahwa, "setiap detik dari hidup adalah untuk dinikmati. Waktu yang mengalir adalah tak henti-hentinya adalah kebahagiaan terbesar bagi yang dapat merasakan., ${ }^{39}$ Dalam hal ini sebagaimana Epikuros juga berpandangan bahwa seseorang harus menikmati setiap waktu yang ada dengan bebas dari rasa takut terhadap dewa-dewa dan kematian sehingga dapat merasakan kebahagiaan. ${ }^{40}$

2. Faktor kebebasan, kebasan merupakan salah satu faktor yang bisa membuat seseorang dapat merasakan kebahagiaan. Saat seseorang hidup dengan kehendak dan tanpa desakan bahkan tanpa tekanan dari orang lain, seseorang itu dapat merasakan sebuah kebahagiaan. Dimana seseorang menjalani kehidupan dengan kehendaknya sendiri. Dan melakukan segala sesuatu atas 
dorongan dirinya sendiri. Sebagaimana digambarkan oleh Kuntowijoyo dalam novel Khotbah Di Atas Bukit bahwa, untuk bahagia seseorang harus bebas dari segala hal yang membuat dirinya merasa tertekan dan resah, “ buku harian akan sangat berguna, tapi tidak. Ia ingin membuang ingataningatan.... Lupakanlah dirimu!." ${ }^{41}$ Terlihat jelas bahwa untuk bahagia seseorang dapat meninggalkan segala hal yang menurutnya tidak baik, bahkan tentang dirinya sendiri. Kuntowijoyo juga menuliskan bahwa dengan kebebasan seseorang dapat menikmati kehidupannya dan dapat menguasai dirinya sendiri. "ia merasa bebas. Tak seorang pun akan melarangnya andaikata ia akan makan, minum, tidur ataupun berak dimana pun ia suka. Ia sadar disinilah baru orang menguasai dirinya sendiri." ${ }^{42}$ Selain itu Kuntowijoyo juga menuliskan bahwa untuk bahagia seseorang akan melepaskan diri dari waktu dan dari beban-beban yang menyiksanya. "Aku ingin melepaskan diri, pop...." dari waktu yang menyiksaku! Dari hidup! Dari beban itu." ${ }^{, 43}$

3. Hidup murni, hidup murni yang dimaksud oleh Kuntowijoyo adalah dimana manusia dapat menjani hidup itu dengan tulus dan tidak dibuat-buat. Sebagaimana Kuntowijoyo menuliskan, “... Hiduplah sekadarnya." Kuntowijoyo juga menuliskan "sudah waktunya bagi laki-laki tua macam dia untuk hidup tulus, murni, sederhana dan tak dibuat-buat.." ${ }^{, 5}$ Dari pandangan di atas, sebagaimana Epikuros juga menghendaki bahwa manusia hendaknya hidup sederhana, harus menghindari apa yang meyakitkan dan pengalamanpengalaman yang tidak mengenakkan. ${ }^{46}$

4. Kesederhanaan. Menurut Epikuros orang bijaksana tidak akan memperbanyak kebutuhannya namun sebaliknya membatasi kebutuhan-kebutuhannya agar dengan membatasi diri dapat menikmati kepuasan. ${ }^{47}$ Terlihat bahwa Epikuros juga menghendaki hidup sederhana. Sebagaimana hal ini digambarkan oleh Kuntowijoyo lewat Humam, hidup sederhana ternyata membuatnya dapat merasakan kebahagiaan hidup.

"Barman memandang lauk pauk di meja. Itu semacam yang belum pernah ditemuinya." 48 "sungguh pun Barman tidak terbiasa dengan kesederhanaan, namun makanan itu baginya sangat menyegarkan. Ia tak tahu apakah daging ayam atau kelinci yang disuguhkan... dan ikan-ikan sungai. Disini tidak ditemukan piring kembang bersih dengan serbetserbet makan, hiasan sayur seperti yang selalu dibuat oleh Popi. Juga tomat itu terguling begitu saja di meja. Ia merasa enak makan dengan cara demikian. ${ }^{, 49}$

Intizar, Vol. 22, No. 1, 2016 
Dari hal di atas Kuntowijoyo ingin menyampaikan bahwa, kebahagian bukan hanya di dapat dari kemewahan namun, kebahagiaan yang sebenarnya adalah di dapat dari kesederhanaan hidup.

5. Kebijaksanaan. Kuntowijoyo dalam novel Khotbah Di Atas Bukit ini menggambarkan bahwa kebijaksanaan hidup akan menghantarkan manusia kepada kebahagian. Karena menurut Kuntowijoyo "kedamaian yang baik itu berasal dari kebijaksanaan." ${ }^{50}$ Orang yang hidupnya bijaksana akan tahu memilih mana yang baik untuknya dan mana yang tidak baik untuknya. Bahkan orang yang bijaksana akan dapat menikmati hidupnya dengan kedamaian jiwa. Sebagimana pandangan di atas sama hal nya dengan Epikuros, dimana Epikuros juga menegaskan kebijaksanaan sebagai seni hidup. Menurut Epikuros orang bijak pandai mempertimbangkan apakah ia memilih nikmat atau rasa sakit. ${ }^{51}$

6. Mengosongkan pikiran. Dalam artian bahwa seseorang dapat mencapai kebahagiaan apabila dia dapat mengosongkan pikiran dari segala hal yang meresahkan jiwa. sebagaimana Kuntowijoyo menuliskan, "mengosongkan pikiran adalah awal dari ketentraman." Selain itu Kuntowijoyo juga menuliskan, "Ia sudah memutuskan bahwa pikiran, ingatan dan cita-cita telah membuatnya menderita selama ini, membuatnya bosan. Sekarang sudah tiba saat ia membebaskan diri.".52

Dari beberapa faktor-faktor di atas bahwa pandangan Kuntowijoyo terhadap kebahagiaan yang terkadung dalam novel Khotbah Di Atas Bukit ini sama halnya dengan Epikuros. Sebagaimana hal ini terlihat dari pandangan Epikuros yang beranggapan bahwa, untuk bahagia seseorang harus menjauhi segala yang membuat kesakitan badan dan jiwa. ${ }^{53}$ Epikuros bergitu menjunjung tinggi kebijaksanaan, karena menurutnya meskipun kesenangan adalah sesuatu yang harus dikejar tapi tidak semua kesenangan harus di cari bila dari sana dapat menimbulkan kemalangan dan kesengsaraan. Maka dari itu dia mencanangkan pola hidup sederhana. ${ }^{54}$

\section{Tanda-Tanda Tercapainya Kebahagiaan}

Tanda-tanda seseorang yang telah mencapai kebahagiaan hidup dalam novel Khotbah Di Atas Bukit karya Kuntowijoyo dapat dilihat dari tiga aspek yaitu aspek penguasaan diri/kebebasan, penghindari apa yang menyakitkan, dan aspek kebijaksanaan. 


\section{Lina Santiana}

\section{Aspek Penguasaan Diri/Kebebasan}

Kata "bebas" dalam kamus besar bahasa Indonesia diartikan lepas sama sekali (tidak terhalang, tidak terganggu dan sebagainya), sehingga dapat bergerak, dapat berbicara, berbuat dan sebagainya dengan leluasa. Adapun "kebebasan" diartikan dengan; kemerdekaan, dan keadaan bebas. ${ }^{55}$

Manusia dikatakan bebas mengandung dua pengertian yaitu dia mampu menentukan diri sendiri, dan ia tidak dibatasi oleh orang lain atau masyarakat dalam kemungkinannya untuk menentukan diri sendiri. Kebebasan terbagi menjadi 3 bagian yaitu kebebasan fisik, artinya kemampuan untuk menggerakkan anggota tubuh. Kebebasan psikis, artinya kemampuan untuk menentukan sendiri apa yang dipikirkan dan dikehendaki, dan kebebasan normatif, artinya keadaan bebas dari larangan atau pewajiban. ${ }^{56}$

Dalam novel ini kebahagiaan bagi Barman berbeda dengan Popi dan Humam. Kebahagiaan bagi Barman adalah kenikmatan dan kemewahan duniawi. Sedangkan Humam melihat kebahagiaan itu dari kesederhanaan, dan pembebasan dari hal yang bersifat material, yang hampir jenis kebahagiaan yang dijalani Barman tidak dimiliki Barman dan Popi. Sedangkan Popi memilih kebahagiaan dengan melepaskan diri dari pikiran-pikiran dan segala hal yang meresahkan dirinya.

Kuntowijoyo menggambarkan bahwa orang yang telah mencapai kebahagiaan dalam novel Khotbah Di Atas Bukit adalah dia mampu menguasai dirinya dan bebas. Sebagaimana tergambar lewat tokoh Humam yang telah mencapai kebahagian, "Untuk apa. Kita tak perlu apa pun lagi. Kita sudah hilang."57

Dalam hal ini, Kuntowijoyo juga ingin menyampaikan bahwa hidup manusia butuh kebebasan dalam hidupnya, untuk mencapai kebahagiaan manusia harus bebas tak memerlukan apa-apa, dan mampu menguasai dirinya sendiri, ibarat menunggang kuda maka kita harus mengendalikan kuda itu jangan sampai kita yang dikendalikan kuda itu. Kuntowijoyo juga menuliskan;

"Jadi bagaimana?"

"Kesendirian adalah hakikat kita, he"

"Anakmu, istrimu, keluargamu. Sahabatmu."

"Semua sudah kulepaskan"

"Semuanya?"

"Ya."

Selain itu, Humam juga mengajarkan bahwa;

Intizar, Vol. 22, No. 1, 2016 
"Kalau engaku memikirkan aku, itu kesalahan bung. Justru karena bertentangan dengan keadaanku. Tidak ada yang perlu dikhawatirkan. Itu sudah berjalan. Dan berjalan dengan baik. Beban itu sudah aku lepaskan". ${ }^{58}$

"Keadaanku ialah ketiadaanku",59

"Hum, apa sesungguhnya yang kau kerjakan dibukit?"

"Justru tak mengerjakan apapun. Hidup sudah selesai bagiku."

"Lupakan semuanya, bahkan dirimu. Yang ada ialah pohon-pohon, rumput-ruput. Engkau makhluk yang paling bahagia. Waktu ialah untuk dinikmati. Ruang ialah tempat kita bergerak. Gerak ialah hidup kita."

"Maksudmu"

"Tidak ada maksud apa-apa."

"Aku tak mengerti."

"Hidup sekadarnya, bahagia sebesarnya."

Barman mencoba mengingat satu-satu kalimat berurutan dari Humam.

"Dan mati?" ia bertanya.

"Ialah kalau kita tak lagi punya gerak."

"Dan engkau tidak takut?"

"Justru yang paling tidak menakutkan.",61

Dari dialog tersebut, Kuntowijoyo ingin mengatakan bahwa seseorang yang telah mencapai kebahagiaan dapat menjalani hidup ini dengan tenang, menikmati setiap waktu yang ada, dan hidup sekadarnya serta bahagia sebesar-besarnya sehingga jiwa menjadi tenang dan damai.

Kuntowijoyo juga menuliskan melalui tokoh Humam“... Kebahagiaan mutlak tak memerlukan apa-apa diluar diri kita." Dan “... hidup sudah selesai bagiku." Artinya disini Kuntowijoyo ingin menyampaikan bahwa orang yang telah mencapai kebahagiaan tidak akan membutuhkan apapun lagi dalam hidupnya. Melepaskan diri sepenuhnya dari hal-hal yang bersifat material, dan menikmati setiap detik dari kehidupan. Sebagaimana dalam hal ini Epikuros mengatakan bahwa jika seseorang yang telah mencapai kebahagiaan dalam hidup ia akan mampu menguasai dirinya, sehat badan dan jiwanya karena mampu memaksimalkan ketenangan dan kebebasan sehingga tercapailah ataraxia. ${ }^{63}$

\section{Menghindari Apa Yang Menyakitkan}

Menurut Epikuros hakikat nikmat adalah terdiri dalam ketentraman jiwa yang tenang, yang tidak dapat dikejutkan dan dibingungkan, kebebasana dari rasa risau 


\section{Lina Santiana}

dan terkejut. Manusia hendaknya menghindari apa yang menyakitkan, dan pengalaman-pengalaman yang tidak mengenakkan. ${ }^{64}$ Pandangan ini sama halnya dengan padangan Kuntowijoyo, yang disampaikannya lewat novel Khotbah Di Atas Bukit. Sebagaimana Kuntowijoyo menggambarkan bahwa, untuk mencapai kebahagian kita harus membuang ingatan, pertanyaan-pertanyaan yang dapat membuat jiwa resah. Sehingga orang yang sudah mencapai kebahagiaan dia akan tahu mana sesuatu yang membuat dia bahagia dan mana pula hal yang membuatnya menderita. Sehingga seseorang itu akan menghindari segala hal yang dapat menyakitkan dirinya dan membuat dirinya menderita. Sebagaimana yang dituliskan Kuntowijoyo;

"Apa lagi yang kau pikirkan pap? Hidup sudah selesai. Tidak ada lagi! Tidak ada! Kalau makanan habis kita cukup mengangkat telepon dan bobi akan mengirimnya. Lupakanlah, kecuali bahwa kita hidup.

Ia telah memutuskan bahwa pikiran, ingatan, cita-cita telah membuatnya menderita selama ini, membuatnya bosan.... Barman selalu mengeluh, karena ia tak mampu menerima hidup sebagaimana yang harus dijalani. Laki-laki tua itu mempunyai bakat untuk menderita; keinginan, pikiran, ingatan dan cita-cita." ${ }^{, 65}$

Dari hal di atas jelas bahwa Kuntowijoyo menggambarkan seseorang yang bahagia dalam hidupnya memilih untuk melepaskan diri dari segala ingatan dan itu membuatnya bahagia. Sebagaimana Kuntowijoyo juga menuliskan, "Setiap detik dari hidup adalah untuk dinikmati. Waktu yang mengalir tak henti-hentinya adalah kebahagiaan terbesar bagi yang dapat merasakan." ${ }^{66}$ Inilah kebahagiaan yang dicapai dengan menikmati setiap waktu dari hidup yang dipilih oleh orang-orang tertentu.

Selain itu, Kuntowijoyo menjelaskan melalui tokoh Popi bahwa manusia yang bahagian itu haruslah hidup dengan hidup yang sesuai dengan kodratnya yaitu hidup yang mempunyai nilai. Segala yang membuat kita menderita harus di singkirkan dan di tinggalkan.

"Hidup yang mempunyai nilai"

"Hidup itu sendiri suatu nilai. Tak ada tambahan yang diperlukan, hh!

Kalau engkau hidup, engkau bermakna. Kalau engkau mati, tidak"

"Selebihnya dari hidup, semuanya sia-sia! Semua omong kosong."

"..... Bahwa yang tak bernilai ialah yang berlawanan dengan hidup.

"Misalnya penyakit... Segalanya yang menyebabkan engkau menderita, sakit dan mendekatkan kematian, harus dipandang sebagai

Intizar, Vol. 22, No. 1, 2016 
kejahatan. Tak lebih. Atau selebihnya adalah lamunan yang sia-sia. Apapun yang membuat hidup, itu bernilai. ${ }^{67}$

\section{Aspek Kebijaksanaan}

Di dalam novel ini, Kuntowijoyo mengambarkan seseorang yang telah mencapai kebahagiaan dapat menguasai dirimu sendiri dan dapat mengambil kebijaksanaan-kebijaksanaan dalam hidup. Sebagaiman Kuntowijoyo menuliskan bahwa, "Biarlah dia bukan mencari ilmu, tetapi kebijaksanaan, bertapa ia bahagia! Pengasingan yang sempurna! Ia selalu tersenyum."68 Ini adalah kebahagiaan yang diperoleh oleh Barman dengan jalan kebijaksaan-kebijaksaan.

Seseorang yang telah mencapai kebahagiaan dalam hidupnya akan menjadi bijaksana. Dia mampu membedakan mana yang baik untuknya. Seseorang mampu melihat bahwa sesuatu itu pantas dan tidak untuk dijalani. Sebagaimana hal ini Kuntowijoyo menggambarkan hal tersebut lewat tokoh Barman yang telah mencapai kebahagiaan hidup setelah sekian lamanya dia bergulat memecahkan segala keresahan dalam dirinya;

"Dipemberhentian Bus itu malam pun berbulan. Binar-binar lampu listrik berbaur dengan cahaya-cahaya bulan. Dibagian tak berlampu, bulan melulur malam, menjadikannya kekuningan. Hidup sedang berhenti di stasiun ini, pikir Barman ketika ia melihat truk yang teronggok di atas aspal ia ingin berbicara dengan seseorang disini siapapun itu. Ada sesuatu yang mesti dikatakannya. Hidup dugu seperti ini adalah dosa pikirnya. Orang-orang yang siang hari hilir mudik dan melepaskan hidup siang hari tanpa mengambil kebijaksanaan. Itu adalah dosa nak."69

"Sekilas telapak kudanya menyentuh krikil. Setiap yang bergerak dari hidup ini, setiap yang terdiam dari hidup ini, ialah untuk dinikmati, Humam mengajarkan. Dugu dalam hening malam. Kebekuan manusia adalah warna hidup yang terkutuk. Betul barang kali mereka sekarang melepaskan diri dari kesibukan dan lupa bahwa mereka itu menderita, tetapi bila mereka terbangun, mereka akan kembali mengejar hidup, mengejar-ngejar secara abadi. Itu semacam mesin-mesin yang berputar-putar tak hentinya. $^{70}$

Kedamaian hanya baik jika berasal dari kebijaksanaan."71

Dari sini jelas bahwa Kuntowijoyo dalam novel ini ingin menyampaikan bahwa sebenarnya kehidupan yang damai itu adalah hidup yang dapat mengambil 


\section{Lina Santiana}

kebijaksanaan hidup dan dapat menguasai dirinya sendiri. Karena dalam kehidupannya manusia tidak boleh terlalu mengejar-ngejar kehidupan. Sebagaimana dalam pandangan Epikuros "Orang bijaksana tidak akan memperbanyak kebutuhan namun sebaliknya membatasi kebutuhan-kebutuhannya agar, dengan membatasi diri, dapat menikmati kepuasan."72

Dari penjelasan di atas, menurut hemat penulis bahwasanya dalam hidup itu manusia selalu mengejar sesuatu yang bernilai dalam hidupnya. Bahkan untuk mencapai tujuan dari hidupnya itu manusia memiliki cara yang berbeda, sesuatu yang mereka anggap itu bisa membuat bahagia. Namun demikian, orang akan merasakan kebahagiaan dan kesenangan jika sudah mencapai apa yang dia ingin. Bahkan orang yang telah mencapai kebahagiaan ini dia tidak akan memerlukan apapun lagi, yang dia tahu sekarang adalah dia hidup dan bahagian. Disini Kuntowijoyo mengambarkan ketenangan itu melalui tokoh Humam yang telah mencapai kebahagiaanya, "Untuk apa. Kita tak perlu apapun lagi. Kita sudah hilang., 73

Dari cuplikan novel ini maka orang yang dalam hidupnya telah mencapai suatu kebahagiaan bahkan untuk kematian bukanlah hal yang menakutkan dan sangat tidak menyakitkan. Disini Kuntowijoyo menjelaskan lewat tokoh Humam bahwa:

"Tetapi mam, hum. Apakah engkau berbahagia?"

"Aku tak percaya bahwa penderitaan itu ada."

"Tetapi lapar, takut, sakit, kecewa, sepi!"

"Aku hanya percaya pada mati, dan itu tidak sakit."

Dari sini dapatlah dilihat Kuntowijoyo ingin menjelaskan bahwa kematian bukanlah hal yang menyakitkan bagi orang yang sudah mencapai kebahagiaan. Jadi dengan datangnya kematian apakah segala sesuatu sudah selesai bagi manusia? Benar, bahkan kematian adalah kemungkinan terakhir. Dan bahkan orang bijak akan menyongsongnya dengan hati yang tenang. Selain kematian bukanlah hal yang menakutkan bagi orang yang telah mencapai kebahagiaan, menurut Kuntowijoyo dalam novel ini, orang yang bahagia pun tak memerlukan apapun lagi dalam hidupnya. “... Engkau pasti pensiunan atau orang kaya bung. Kebukit untuk mencari tempat istirahat. Itulah yang mengganggumu. Istirahat berarti ingin sesuatu. Itu kesalahanmu. Aku tak punya keinginan lagi. Juga istirahat." $^{, 74}$

Intizar, Vol. 22, No. 1, 2016 
Menurut hemat penulis disini terlihat bahwa Kuntowijoyo ingin menunjukkan kepada pembaca bahwa seseorang hendaknya hidup tulus, muni, sederhana dan tidak berlebih-lebihan. Dan hiduplah sebagaimana mestinya agar dapat hidup bahagia. Karna menurut Kuntowijoyo "kalau kita tak menginginkan apapun dari milik kita, maka kita telah membebaskan diri."

Melalui tokoh Humam Kuntowijoyo menunjukkan setiap manusia itu hendaknya dapat hidup sederhana. Sejatinya kebahagiaaan itu adalah suatu hal yang diinginkan manusia dan senantiasa menjadi tujuan manusia, maka untuk mendapatkannya pun manusia memiliki cara masing-masing. Sebagaimana dalam novel Khotbah Di Atas Bukit ini. Kuntowijoyo mengambarkan lewat Popi yang mencari kebahagiaan dengan berhenti berpikir dan menghilangkan keinginankeinginan dan ingatan-ingatan yang dapat meresahkan jiwa, Humam yang meninggalakan segala bentuk kehidupan mewah, dan kehidupan sosialnya.

Hingga pada puncak terakhir novel ini Barman memutuskan untuk bunuh diri. Barman menerjunkan diri dari puncak bukit, setelah menyampaikan khotbahnya. " Bunuhlah dirimu" dan " Hidup tak berharga untuk dilanjutkan"75 melihat kondisi ini akhirnya pengikut Barman pun mengalami kegundahan dan sebagian lain mengikuti jejak Barman dan bunuh diri.

Berdasarkan analisis penulis bahwa dari novel tersebut, seseorang yang telah mendapatkan kebahagiaan hidupkannya tidak akan resah, jiwanya akan damai dan tidak membutuhkan apapun lagi dalam hidupnya bahkan tidak ada rasa takut dalam dirinya. Karena orang bijak menghadapi segala situasi apa pun dengan hati yang lapang, sekalipun itu adalah kematian. Berdasarkan kenyataan, banyak manusia yang tidak bahagia karena mengalami ketakutan-ketakutan dalam hidupnya. Jadi apabila manusia telah dapat menghilangkan ketakutan itu, niscaya manusia akan mencapai ketenangan jiwa, yang selanjutnya akan mencapai kebahagiaan hidup. Dan untuk mencapai kebahagiaan hidup tersebut oleh Kuntowijoyo melalui novel Khotbah Di Atas Bukitnya bahwa manusia harus memperhatikan keutamaan yaitu hidup sederhana, tahu diri, penguasaan diri, dan kegembiraan pada semua situasi. Meskipun di akhir dari cerita ini adalah Barman dan pengikutnya memilih untuk bunuh diri. Tapi itulah cara manusia untuk mencapai apa yang ditujunya. Sekalipun itu sesuai atau tidak dengan norma-norma dalam kehidupan. Apakah manusia akan berbuat sesuai dengan tujuan hidupnya atau tidak, semua menjadi pilihan masing-masing manusia yang dianggap baik olehnya.

Intizar, Vol. 22, No. 1, 2016 


\section{Lina Santiana}

\section{Kesimpulan}

Novel Khotbah Di Atas Bukit karya Kuntowijoyo mengandung nilai-nilai etika kebahagiaan yang sama dengan Epikuros. Nilai-nilai etika kebahagiaan dalam novel Khotbah Di Atas Bukit ini di tuangkan secara khas oleh Kuntowijoyo, yaitu lembut dan penuh makna. Bahkan nilai-nilai etika kebahagiaan dalam novel Khotbah Di Atas Bukit karya kuntowijoyo ini terungkap melalui dialog yang melatar belakangi masalah-masalah dalam novel Khotbah Di Atas Bukit.

Dalam pandangan Epikuros Kesenangan adalah prinsip serta tujuan dari hidup bahagia. Untuk mencapai itu manusia harus mencari nikmat sedapatdapatnya dan sebanyak-banyaknya. Oleh karena itu, maka manusia harus menjauhi segala yang membuat jiwa resah dan kesakitan badan. Meskipun pada dasarnya setiap kesenangan bisa dinilai baik, namun itu tidak berarti bahwa setiap kesenangan harus dicari.

Dalam novel Khotbah Di Atas Bukit, pengarang menggambarkan kehidupan manusia yang mencari-cari kebahagiaan dalam hidupnya. Dan tak jarang untuk mendapatkan kebahagiaan itu Kuntowijoyo melalui novel ini ingin mengambarkan bahwa, manusia harus hidup secara murni, tulus, sederhana dan tidak dibuat-buat. Dalam kehidupan ini manusia harus dapat mengambil kebijaksaan hidup sehingga dapat bahagia. Maka untuk mencapai kebahagiaan dalam Novel Khotbah Di Atas Bukit karya Kuntowijoyo lebih menekankan keutamaan-keutamaan seperti penguasaan diri atau kebebasan, menghindari apa yang menyakitkan dan kebijaksanaan. 


\section{Endnote}

${ }^{1}$ W. Poespoprodjo, Filsafat Moral Kesusilaan Dalam Teori Dan Praktek, (Bandung: Ramadja Karya, 1988), hlm. 30

2 Anwar Sanusi, Jalan Kebahagiaan, (Jakarta: Gema Insani Press, 2006), hlm. 2

${ }^{3}$ Bambang Rudianto Sudrijanta, dkk, Jelajah Hakikat Pemikiran Timur, (Jakarta: Gramedia Pustaka Utama, 2004), hlm. 63

${ }^{4}$ Ibid., hlm. 71

5 Taoisme adalah suatu filsafat yang menduduki tempat terpenting di cina. Pengaruhnya terhadap kebudayaan cina memang tidak sebesar konfusianisme, akan tetapi taoisme mempunyai pandangan metafisika dan spekulatif terhadap kodrat realitas, alam semesta, dan manusia. Kata taoisme diturunkan dari kata tao, jalan. Pendiri taoisme ini adalah Lao Tzu. Kitab suci taoisme ini adalah Tao Te Ching. Lihat pada Bambang Rudianto, Sudrijanta, dkk, Jelajah Hakikat Pemikiran Timur ..., hlm. 75

${ }^{6}$ Tao adalah suatu bentuk pemikiran yang ada dalam ajaran taoisme. Tao adalah pintu masuk segala hakikat misteri. Tao adalah sumber segala sesuatu dan sumber segala fenomena. Sebelum surga dan bumi ada, tao sudah ada. Tao adalah tujuan segala sesuatu.

${ }^{7}$ Ibid., hlm. 78

${ }^{8}$ Ibid., hlm. 150

${ }^{9}$ Lorens Bagus, Kamus Filsafat, (Jakarta: Gramedia Pustaka Utama, 1996), hlm. 282

${ }^{10}$ Berfilsafat oleh Epikuros dianggap juga suatu kegiatan manusiawi yang sangat perlu, karena kita tak pernah terlalu muda untuk memulainya dan tak pernah terlalu tua untuk mengakhirinya; " kalau anda masih muda janganlah ragu-ragu untuk berfilsafat. Sebab, tak pernah dapat dikatakan bahwa seseorang terlalu muda atau terlalu tua untuk menekuni kesehatan jiwa. Mengatakan bahwa saat terlalu pagi ataupun terlalu lambat untuk berfilsafat, sama dengan mengatakan bahwa. Waktunya terlalu pagi ataupun terlabat untuk berbahagia. Baik orang muda atau pun kakek harus mendalami filsafat; yang terakhir untuk mempermuda dirinya melalui kontak hidup dengan Hal-hal yang indah dari masa lalu dan yang pertama supaya dan bahkan di masa mudanya ia berdiri tegak menghadap hari depan, sama seperti seorang kakek."

${ }^{11}$ P. A.Van Der Weij diindonesiakan oleh K. Bertens, Filsuf-Filsuf Besar Tentang Manusia, (Jakarta: Gramedia, 1988), hlm. 59

${ }_{12}$ Muhammad Mufid, Etika Dan Filsafat Komunikasi, (Jakarta: Kencana Prenada Media Group, 2009), hlm. 181 hlm. 15

${ }^{13}$ Syefriyeni, Etika Dasar-Dasar Etika, (Palembang: IAIN Raden Fatah Press, 2006),

${ }^{14}$ Ibid., hlm. 22

${ }^{15}$ Kuntowijoyo, Budaya Dan Masyarakat, (Yogyakarta: Tiara Wacana, 1987), hlm. 105

${ }^{16}$ Franz Magni Suseno, Etika Dasar, (Yogyakarya: Kanisius, 1987), hlm. 13

${ }^{17}$ W. Poespoprodjo, Filsafat Moral ..., Op.Cit., hlm 18

${ }^{18}$ Ibid., hlm. 52

${ }^{19}$ Erich Fromm, Lari Dari Kebebasan, (Yogyakarta: Pustaka Pelajar, 1997), hlm. 257

${ }^{20}$ Rusli Amin, Pencerahan Spiritual: Sukses Membangun Hidup Damai Dan Bahagia, (Jakarta Selatan: Al-Mawardi Prima, 2003), hlm. i 
${ }^{21}$ W. Poespoprodjo, Filsafat Moral ..., Op.Cit., hlm. 30

${ }^{22}$ P. A.Van Der Weij diindonesiakan oleh K. Bertens, Filsuf-Filsuf Besar ..., Op.Cit., hlm. 60

${ }^{23}$ Kuntowijoyo, Khotbah Di Atas Bukit, (Yogyakarta: Bentang Budaya, 1997), hlm. 65

${ }^{24}$ Ibid., hlm. 35

${ }^{25}$ Ibid., hlm. 66

${ }^{26}$ Ibid., hlm. 79

${ }^{27}$ Ibid., hlm. 84

${ }^{28}$ Ibid., hlm. 113

${ }^{29}$ Ibid., hlm. 74

${ }^{30}$ Ibid., hlm. 63

${ }^{31}$ Ibid., hlm. 68

${ }^{32}$ Ibid., hlm. 72

${ }^{33}$ Ibid., hlm. 72

${ }^{34}$ Ibid., hlm. 108

${ }^{35}$ K. Bertens, Etika, (Jakarta: Gamedia Pustaka Utama, Jakarta, 2004), hlm. 236-237

${ }^{36}$ Syefriyeni, Etika Dasar-Dasar ..., Op.Cit., hlm. 37

${ }^{37}$ Kuntowijoyo, Khotbah Di ..., Op.Cit., hlm. 72

${ }^{38}$ Ibid., hlm. 161

${ }^{39}$ Ibid., hlm. 104

${ }^{40}$ P. A. Van Der Weij, Filsuf-Filsuf Besar..., Op.Cit., hlm. 64

${ }^{41}$ Kuntowijoyo, Khotbah Di ..., Op.Cit., hlm. 59

${ }^{42}$ Ibid., hlm. 80

${ }^{43}$ Ibid., hlm. 103

${ }^{44}$ Ibid., hlm. 143

${ }^{45}$ Ibid., hlm. 158

${ }^{46}$ Syefriyeni, Etika Dasar-Dasar Filsafat Moral ..., Op.Cit., hlm. 36

${ }^{47}$ Ibid., hlm. 37

${ }^{48}$ Kuntowijoyo, Khotbah Di ..., Op.Cit., hlm. 66

${ }^{49}$ Ibid., hlm. 67

${ }^{50}$ Ibid., hlm. 162

${ }^{51}$ Syefriyeni, Etika Dasar-Dasar ..., Op.Cit., hlm. 36

${ }^{52}$ Kuntowijoyo, Khotbah Di Atas Bukit ..., Op.Cit.,hlm. 100 hlm. 61

${ }^{53}$ P. A.Van Der Weij diindonesiakan oleh k. Bertens, Filsuf-Filsuf Besar ..., Op.Cit.,

${ }^{54}$ K. Bertens, Etika ..., Op.Cit., hlm. 237

${ }^{55}$ Syefriyeni, Etika Dasar-Dasar Etika ..., Op.Cit., hlm. 115

${ }^{56}$ Franz Magnis Suseno, K. Bertens, dkk, Etika Social Buku Panduan Mahasiswa PB I-PB IV, (Jakarta: Gramedia Pustaka Utama, 1993), hlm. 18-20. Juga lihat K. Bertens, Etika, (Jakarta: Gramedia Pustaka Utama, 2004), hlm. 103-109

${ }^{57}$ Kuntowijoyo, Khotbah Di Atas ..., Op.Cit., hlm. 69

${ }^{58}$ Ibid., hlm. 70

${ }^{59}$ Ibid., hlm. 71 
${ }^{60}$ Ibid., hlm. 75

${ }^{61}$ Ibid., hlm. 72-73

${ }^{62}$ Ibid., hlm. 75

${ }^{63}$ K. Bertens, Etika ..., Op.Cit., hlm. 237

${ }^{64}$ Syefriyeni, Etika Dasar-Dasar Filsafat Moral ..., Op.Cit., hlm. 36

${ }^{65}$ Kuntowijoyo, Khotbah Di Atas ..., Op.Cit., hlm. 100

${ }^{66}$ Ibid., hlm. 104

${ }^{67}$ Ibid., hlm. 108

${ }^{68}$ Ibid., hlm. 151

${ }^{69}$ Ibid., hlm. 160

${ }^{70}$ Ibid., hlm. 161

${ }^{71}$ Ibid., hlm. 162

${ }^{72}$ Syefriyeni, Etika Dasar-Dasar ..., Op.Cit., hlm. 37

${ }^{73}$ Kuntowijoyo, Khotbah Di Atas ..., Op.Cit., hlm. 69

${ }^{74}$ Ibid., hlm. 75

${ }^{75}$ Ibid., hlm. 232

\section{Daftar Pustaka}

Amin, Rusli. (2003). Pencerahan Spiritual: Sukses Membangun Hidup Damai Dan Bahagia. Jakarta Selatan: Al-Mawardi Prima.

Bagus, Lorens. (1996). Kamus Filsafat. Jakarta: Gramedia Pustaka Utama.

Bertens, K. (1988). Filsuf-Filsuf Besar Tentang Manusia. Jakarta: Gramedia. . (1999). Sejarah Filsafat Yunani. Yogyakarta: Penerbit Kanisius Anggota IKAPI. . (2004). Etika. Jakarta: Gramedia Pustaka Utama.

Erich, Fromm. (1997). Lari Dari Kebebasan. Yogyakarta: Pustaka Pelajar Anggota IKAPI.

Fahmi, M. (2005). Islam Transendental Menelusuri Jejak-Jejak Pemikiran Islam Kuntowijoyo. Yogyakarta: Pilar Religion.

Kuntowijoyo. (1987). Budaya Dan Masyarakat. Yogyakarta: Tiara Wacana. . (1997). Khotbah Di Atas Bukit. Yogyakarta: Bentang Budaya.

Mufid, Muhammad, Etika Dan Filsafat Komunikasi, Kencana Prenada Media Group, Jakarta, 2009.

Poespoprodjo, W. (1988). Filsafat Moral Kesusilaan Dalam Teori Dan Praktek. Bandung: Ramadja Karya.

Sanusi, Anwar. (2006). Jalan Kebahagiaan. Jakarta: Gema Insani Press.

Sudrijanta Bambang Rudianto, dkk. (2004). Jelajah Hakikat Pemikiran Timur. Jakarta: Gramedia Pustaka Utama.

Suseno, Franz Magni. (1987). Etika Dasar. Yogyakarya: Kanisius. 
Suseno, Franz Magnis Suseno dkk. (1993). Etika Social Buku Panduan Mahasiswa PB I-PB IV. Jakarta: Gramedia Pustaka Utama.

Syefriyeni. (2006). Etika Dasar-Dasar Etika. Palembang: IAIN Raden Fatah Press. 